This item was submitted to Loughborough's Research Repository by the author.

Items in Figshare are protected by copyright, with all rights reserved, unless otherwise indicated.

\title{
Crime, inequality and change in England and Wales
}

PLEASE CITE THE PUBLISHED VERSION

http://www.palgraveconnect.com/pc/doifinder/10.1057/9781137291462

\section{PUBLISHER}

Palgrave Macmillan

VERSION

AM (Accepted Manuscript)

\section{PUBLISHER STATEMENT}

This work is made available according to the conditions of the Creative Commons Attribution-NonCommercialNoDerivatives 4.0 International (CC BY-NC-ND 4.0) licence. Full details of this licence are available at: https://creativecommons.org/licenses/by-nc-nd/4.0/

\section{LICENCE}

CC BY-NC-ND 4.0

\section{REPOSITORY RECORD}

Grove, Louise E., Andromachi Tseloni, and Nick Tilley. 2019. "Crime, Inequality and Change in England and Wales". figshare. https://hdl.handle.net/2134/16130. 


\title{
Crime, inequality and change in England and Wales
}

\author{
Louise Grove $^{1}$, Andromachi Tseloni ${ }^{2}$ and Nick Tilley ${ }^{3}$
}

\section{Introduction}

Since the 1970s criminological research has turned its attention increasingly to the plight of victims, to victim typologies and to patterns of victimization. This is in contrast to offender typologies and explanations of crime patterns by reference to criminal propensities, which previously comprised criminology's almost exclusive focus (see, for instance, Karmen 2001). In their seminal study, using bivariate analyses to compare specific socio-demographic groups to the rest for individual crime types, Hindelang, Gottfredson, and Garofalo (1978) identified sub-groups at high risk of victimization. They drew on US data from the forerunner to the National Criminal Victimization Survey (NCVS). Their lifestyle theory, according to which crime levels are a function of exposure to risk which in turn is a function of styles of life, developed from these empirical results and is still relevant today albeit with some notable improvements (Lauritsen, 2001; Tseloni, 2006).

At about the same time that Hindelang et al were writing, routine activities theory, which still informs much research on patterns of victimization research and guides much of this book's discussion, used time series analysis to link changes in crime patterns to changes

\footnotetext{
${ }^{1}$ University of Loughborough, UK.

${ }^{2}$ Nottingham Trent University, UK.

${ }^{3}$ Jill Dando Institute, University College London, UK.
} 
in aspects of everyday life that brought together the conditions for crime to take place: the co-presence of a likely offender, a suitable targets and absence of a capable guardian (Cohen and Felson, 1979). The two theories have since been brought together and empirical research has tested amalgamated lifestyle/ routine activities theory across different settings at the micro- and/or macro- level, i.e., across individuals, households, areas, regions or entire countries (Gottfredson, 1981; see for instance, Miethe, Stafford and Long, 1987).

Over the last thirty years, a number of developments, such as the launch of the British Crime Survey (BCS) in 1982 and of the International Crime Victims Survey (ICVS) in 1989 providing strong data on patterns of victimization; recognition of the importance of repeat victimization; and the application of hierarchical statistical modeling techniques to disentangle individual and contextual variables, have significantly improved our ability to identify victimization patterns. Nevertheless, we have not yet fully understood the causal mechanisms producing victimization patterns and changes in them. Moreover, until recently we have lacked longitudinal panel design data sets with the information needed to test our theories.

In short, empirical research to date has shown that prior crime experiences, young age, lone parenthood and adverse socio-economic backgrounds, such as social renting and multiple occupancy households, increase risk of criminal victimization. Lifestyle and routine activities effects however are conditional on demographic characteristics, while area of residence conditions individual risks, especially for property crimes (Tseloni, $2006 ; 2010)$. In addition, the rank order of population subgroups in terms of vulnerability to victimization is crime-specific (Tseloni, Osborn, Trickett and Pease, 2002). 
Fortunately, only a minority of the general population are victims of crime in a single year, although some suffer a disproportionate number of incidents (Tseloni and Pease, 2005).

This chapter considers whether the sizeable crime drops of the last twenty years or so have altered crime inequalities, and, if so in what ways. Drawing on BCS data, the falls in domestic burglary, personal crime and vehicle theft in England and Wales from 1995 to 2009-10 are examined. The crime types have been selected because of their large contribution to overall crime rates. The crime drop in England and Wales was unexpected and unprecedented. It was, however, found also in many other countries (Tseloni, Mailley, Farrell and Tilley, 2010). In contrast to other papers forming parts of the same program of work as this one (Farrell, Tseloni, Tilley and Mailley, 2011a; Farrell, Tseloni and Tilley, 2011b), the present chapter is not concerned with the causes of those falls. Rather, building on Tilley, Tseloni and Farrell (2011), it examines whether any changes in crime inequality are associated with the falls. Three socio-economic attributes will be examined here: tenure, household income and household composition. As already indicated, these variables are among the most relevant to victimization risk, as suggested in theory and as corroborated in simple cross-tabulations. They are also found, in regression analyses, to operate independently of other factors. Thus, in this chapter our specific question is, 'To what extent, if at all, have the falls in domestic burglary, vehicle theft and personal crime victimization led either exacerbated or ameliorated levels of subgroup risk variation?'

The next section describes the data and the methodology used in this work and outlines the overall trends in domestic burglary, car crime and personal crime in England and 
Wales. The patterns of crime inequality across population subgroups with respect to household income, household composition, and tenure are discussed thereafter with respect to the end points of the overall period included in the analysis. Section 4 explores whether the crime drops are consistent across the population subgroups in question and the chapter concludes with a discussion of the results.

\section{Data, Methodology and Context}

The analysis in this section draws on eight sweeps of the BCS, from 1996 to 2009-10, while the remainder of the chapter uses estimates from the two end years. The 1996 BCS, which measured crime rates for the 1995 calendar year (Hales and Stratford, 1997), had a sample of 16,348 respondents. By the 2009-10 BCS, which measured crimes in that financial year (April 2009 to March 2010, TNS-BMRB, 2010), the sample had grown to 44,638 participants. The BCS is a national crime survey for England and Wales. Between 1982 and 2001 it was undertaken biennially. Since 2001-02 it has been conducted as a continuous annual sampling survey. It selects a multistage stratified sample, which is representative of the adult (16 years or older) population living in private accommodation in England and Wales. The BCS questionnaire is comprised of different modules, such as the Main Questionnaire, which collects information on socio-demographic characteristics, routine activities and crime perceptions of respondents, and the Victim Forms, which record detailed information about victims' crime incidents. The crime estimates for this analysis are based on Victim Forms data merged with information on respondents' characteristics from the Main Questionnaire. 
The three crime categories examined in this chapter comprise domestic burglary, personal crime and vehicle theft. Personal crime includes violence against the person, robbery and theft from the person. Vehicle theft refers to theft of and from motor vehicles, but not damage to them or thefts relating to motorcycles. Collectively, these crime types made up 41.4 per cent and 33.9 per cent of all crimes included in the British Crime Survey in 1996 and 2009-10, respectively. Households are the units of analysis for domestic burglary, in which the target is fixed to the area of residence. In personal crime the individual is the unit of analysis. However, because the BCS sweeps drawn on in this chapter involved interviews only with those aged sixteen and over, it is likely that personal crimes will be under-estimated. In motor vehicle theft, the unit of the analysis is the car owning household. This study focuses on prevalence rates or risks (proportion of the relevant population experiencing one or more incidents of the given crime type) rather than incidence rates (number of incidents of the same crime type over the relevant population) in the twelve months of 1995 and April 2009 to March 2010. Burglary and personal crime risks are based on the number of respondents, since only one person per household is interviewed in the $\mathrm{BCS}^{\mathrm{i}}$. For vehicle crimes prevalence is calculated in relation to car owning households.

As already mentioned, crime risk changes are examined in relation to three characteristics, household income, tenure and composition, which both theory and previous research have identified as important predictors of victimization. In this study, these population subgroups have been identified through common variables that can be created across BCS sweeps, although the indicators are not perfect. The income groups employed here, for instance, entail diminishing real value over time due to inflation. 
Therefore those in the bottom category are relatively poorer in the later sweeps while what was a relatively high income in the early sweeps becomes more modest in the later ones. Indeed, a higher top income category has been added since the 1998 sweep. The weakness of tenure relates to the changes in the overall distribution of tenure types over time. Finally, household composition comprises some heterogeneous categories. For instance, '1-2 adults with no children' includes both retired people and young people who have not yet started families. Their circumstances and lifestyles are likely to be very different.

The analysis and discussion of the following sections are based on simple bivariate associations between each socio-economic characteristic and each crime type examined here, drawing on the 1996 and 2009-10 sweeps of the BCS. The result is 18 relative risk cross-tabulations. Their respective statistical significance is indicated via $\chi^{2}$ statistic values given in the results tables. All estimated associations were highly statistically significant. This work is a preliminary step in examining crime inequality and the crime drop and as such it offers fresh insights into a much neglected aspect of crime trends to date. It is not, however, without caveats since, as the Discussion section points out, relying on cross-tabulations may confound the effects of individual socio-demographic characteristics. In addition, examining the end points of the (up-to-date) period of crime falls fails to identify any turning points in crime inequality trends. The next paragraph discusses the overall crime drops in England and Wales that make up the baseline against which crime inequality is investigated in the main parts of this chapter.

Figure 1 shows the percentage of households, individuals and car owners who suffered respectively domestic burglary, personal crime and car theft in the BCS sweep years from 
1996 to $2009-10$. What is clear is that there was a continuing and very substantial fall in all three crime categories. Overall, vehicle theft fell by 75 per cent, domestic burglary by 69 per cent and personal crime by 53 per cent during the period covered. This followed, of course, a much longer sustained rise in crime, especially following the Second World War.

\section{$<$ FIGURE 1 ABOUT HERE $>$}

\section{Patterns of inequality in levels of victimization}

Table 1 shows the variations in crime rate for domestic burglary, vehicle theft and personal crime by tenure, income and household composition in 1995, the first year in the trends examined in this paper. As we shall see, some differences in levels of victimization mirror other forms of inequality, whereas others do not do so.

\section{$<$ TABLE 1 ABOUT HERE $>$}

Let us examine domestic burglary first. In 1995 just less than one in ten of those with a household income of $£ 4,999$ and under ( 9.8 per cent) experienced one or more burglaries (with or without entry). In all other income groups $(£ 5,000-£ 5,999 ; £ 10,000-£ 19,999$; $£ 20,000-£ 29,000 ; £ 30,000$ and over) between 6.1 per cent and 6.9 per cent suffered one or more burglary. If only burglary with entry is considered, as shown in Table 1 the same basic pattern is found: amongst those in the lowest income group 5.6 per cent were victims with the remainder falling between 3.5 per cent and 4.1 per cent. 
With regards to household composition, single-parent families are at substantially higher risk of burglary than other types. Around one in six (17.6 per cent) were victims of at least one burglary (with or without entry) in the previous year, compared to between 6 per cent and 7.5 per cent for all other household types (2-3 adults with children; $1-2$ adults with no children; 3 or more adults with no children). Likewise, if only burglary with entry is considered, 10.4 per cent of single-parent households experienced one or more incidents, compared to between 3.5 per cent and 3.9 per cent of the other household types.

Finally, with regard to tenure, Table 1 shows that only 3.5 per cent of owner occupiers experienced burglary with entry, compared to between 5.9 per cent and 6.2 per cent of those with other tenure types (social housing; private rental; other). For burglary (with or without entry), owner occupiers were again at lower risk (6.1 per cent) compared with other tenure types, amongst whom between 8.6 per cent and 10.2 per cent experienced burglary with or without entry. In the case of burglary, it appears that in 1995 substantially heightened risk of domestic burglary was associated with low income and with membership of a single parent household, whereas substantially reduced risk was associated with owner occupancy. The figures for burglary with and without entry, which are not shown in Table 1 for economy, are available from the first author.

We turn now to personal crime. In 1995 the risks amongst those in different groups varied from 8.9 per cent for those in households with incomes of $£ 5,000$ to $£ 9,999$ to 13.2 per cent for those in households with incomes of $£ 30,000$ or more. Those in households with incomes of less than $£ 5,000$ had a rate of 11.6 per cent. Those in bands between $£ 5,000$ and $£ 30,000$ and more had gradually increasing rates. In relation to household 
composition, members of single-parent households suffered personal crimes at a substantially higher rate than other groups, at 21.5 per cent. By contrast, 14.5 per cent, 12.3 per cent and just 9.4 per cent of individuals in households with three or more adults without children, 2-3 adults and children and three or more adults and no children experienced personal crime, respectively. With regards to tenure, adults in owneroccupied dwellings experienced the lowest personal crime risk, at 9.9 per cent, rising to 19.7 per cent for private renters. Roughly 13 per cent of adults in social rented or other accommodation experienced personal crime.

These findings suggest that the overall patterns for personal crime are less straightforward than those for domestic burglary. Although lone parenthood and owner occupancy conferred respectively higher and lower risks than those shown for other groups, household income presents a different pattern. Here risk increased along with income, whilst the poorest also had a relatively higher rate than those in middle income groups, showing a U-shaped distribution. Being quite poor but not amongst the very poorest was associated with relatively low risk. A possible explanation is that those in the $£ 5,000$ - $£ 9,999$ category may include relatively more pensioner households who have lower victimization risks than others. A complete socio-demographic profile of the lowest two income groups, and how they differ from the rest in the 1996 BCS, can be found in Tilley et al. (2011), page 301.

Rates of theft of and from vehicles amongst car/van owning households varied by income in 1995, with the two upper (household annual income of $£ 30,000$ or more and $£ 20,000$ to $£ 29,999$ ) and the lowest (household income of $£ 4,999$ or less) income groups experiencing the highest risks, respectively at 20 per cent, 18 per cent and 17.6 per cent. 
Households in the middle income groups were at lower risk of car theft (between 14 per cent and 15.3 per cent). The car theft inequality across household composition subgroups, mirrored that for personal theft: 23 per cent of single parent households were victimized, closely followed by 21.5 per cent of those with three or more adults without children. Only 13.9 per cent of car owners in households comprised of one to two adults without children suffered car theft, as did 18.5 per cent of those in households with two to three adults and children. As with burglary and personal crime, owner-occupiers experienced lower car theft prevalence rates (15.9 per cent) than those with other types of tenure. Private renters had the highest risk of car theft (21.3 per cent), as they also did for personal crime.

The above discussion clearly shows that single parents were consistently at considerably higher crime risk than others in 1995. It is equally evident that owner-occupiers were at lower crime risk than others across the board. Patterns relating to household income are, however, less consistent: car owning affluent households were at relatively high risk of vehicle theft and likewise their adult members had relatively high personal crime risks. Affluent households, however, experienced relatively modest burglary risks compared to those in the lowest income category, which had the highest prevalence rate for this crime type. The poorest, however, did not experience an especially high rate of personal crime and this group's car owners experienced only a slightly higher rate than that for all households (17.6 per cent against an overall 16.7 per cent).

Crime inequality changes during the crime falls. 
The distributions of crime risks across population subgroups in England and Wales described in the previous section agree with previous empirical research and victimization theory (Tseloni et al., 2002). This section asks whether there have been alterations in these distributions over time, as crime levels have fallen. Table 2 repeats the information given earlier in Table 1 but for the 2009-10 BCS, while Table 3 shows the percentage changes in crime risks between 1995 and 2009-10 across the different population subgroups of interest in this work.

$<$ TABLE 2 ABOUT HERE $>$

The breadth of falls in the crimes included in the analysis here is indicated by the fact that there were drops for all types of crime in all the sub-groups included in the analysis. The depth of the falls is shown by the fact that in 40 out of the 42 comparisons made here, the highest 2009/10 rates were lower than the lowest rates in 1995. The exceptions relate to two crime type/population subgroup configurations: a) personal crime/income and b) domestic burglary with entry/household composition. In relation to a) the lowest 1995 risk of personal crime, at 8.9 per cent, against adults of households with $£ 5,000$ to $£ 5,999$ annual income, is lower than the 2009-10 risk (9.6 per cent) faced by adult members of households with $£ 4,999$ or less. With regards to b) the 2009-10 single parents’ risk of 3.7 per cent marginally exceeds the lowest 1995 risk, that for households of three or more adults without children ( 3.5 per cent). But, even in the two cases where the highest subgroup rate for 2009/10 exceeded the lowest sub-group rate in 1995, it was only by small amounts. In short, all subgroups were better off in crime risk terms in 2009/10 
compared to 1995 and almost all subgroups experienced lower crime rates in 2009/10 than those with the lowest risks in 1995.

\section{$<$ TABLE 3 ABOUT HERE $>$}

Table 3 shows that falls in vehicle theft are unrelated to tenure, but that income and household composition do make a difference. Poorer households experienced lower falls than those in higher income categories, exacerbating the initial car theft risk differentials. Households comprising one to two adults without children began with relatively lower risks and then experienced a somewhat steeper decline than other household types. Therefore, during the falls they became even better off than other groups in terms of car theft risks. With regards to domestic burglary with entry, owner occupiers had a substantially lower risk than others in 1995 and experienced greater burglary falls than those with other tenure types. In each of these three cases, crime falls reinforced the initial crime inequalities. The pattern differs, however, for personal crime: adults in rented accommodation, who were at the highest risk compared to others in 1995, saw the steepest falls by 2009-10. Therefore personal crime differentials have diminished somewhat over time. The patterns of change are, thus, quite complex and far from homogenous. The following sets of bullet points summarize them.

The key patterns of continuity, divergence and convergence in the falls from 1995 to 2009-10 in England and Wales are as follows:

\section{Major overall patterns of crime drop}


- Substantial falls in prevalence rates for vehicle theft, burglary and personal crime between 1995 to 2009-10 were found amongst all population subgroups classified by tenure, household income and composition.

- For all clusters, crime drops between 1995 and 2009-10 were greatest for vehicle theft followed by burglary while the lowest falls refer to personal crime.

\section{Major tenure and crime drop patterns}

- Owner occupiers had initially (in 1995) lower risks of vehicle theft, burglary and personal crime than others. Since they experienced higher or equal prevalence drops to 2009-10 in comparison with other tenure groups their relative advantage in crime 'proofing' did not diminish over time.

- Private renters had in 1995 a substantially higher rate of personal crime than others but they also experienced the greatest reduction in risks by this crime type to 2009-10. Therefore their relative personal crime vulnerability diminished over time.

Major household composition and crime drop patterns

- Single parent households were in 1995 most affected by all crime types examined in this chapter and continued in 2009-10 to experience higher risks than others. 
- By contrast, households comprising one to two adults without children exhibited roughly the lowest risks of vehicle theft, burglary and personal crime both in 1995 and 2009-10.

- The rank order of crime risks by household types did not change significantly between 1995 and 2009-10. For vehicle theft and personal crime in both the 1996 and 2009-10, going from highest to lowest risk, the order remained 1) single parent household, 2) three or more adults without children, 3) two to three adults with children, and 4) one to two adults without children. The second to fourth most vulnerable household types of the above rank order collapse into one category, i.e., non-single parents, when burglary is considered. Single parent households were by far the most vulnerable to burglary both in 1995 and 2009-10, while all other household types had rather similar risks.

- Single parents experienced relatively modest falls in vehicle theft and burglary but a higher percentage drop in personal crime compared to other household types.

- Overall in relation to household composition, there were few signs of convergence and some of growing divergence between 1995 and 2009-10.

\section{Major income group and crime drop patterns}


- In both 1995 and 2009-10, the lowest and highest income groups experienced higher prevalence rates of vehicle theft, domestic burglary and personal crime than those in the middle incomes.

- Those belonging to the lowest household income group (less than $£ 10,000$ per annum) experienced substantially smaller drops in personal crime between 1995 and 2009-10 than those in other household income groups. This increased the personal crime risk inequality across income groups. In 1995 the ratio of highest to lowest personal crime risk was 1.5 , with the highest faced by those in households with incomes of $£ 30,000$ or more and the lowest by those in households with incomes of $£ 5,000-£ 9,999$. This ratio increased to 2 by 2009-10, with those in the poorest households (those with incomes of less than $£ 5,000$ ) and those in households with incomes of between $£ 10,000$ and $£ 19,999$ respectively facing the highest and the lowest risks. There was, thus, divergence, of personal crime risks across income groups over time. Those in the lower middle income groups retained their comparative advantage.

- As with personal crime, but in a less pronounced manner, vehicle theft risks fell less for the lower income groups than others. This again contributed to some increase in vehicle theft inequalities from a highest to lowest odds ratio of 1.4 in 1995 (with the highest faced by households of $£ 30,000$ or more and the lowest by those at $£ 5,000$ to $£ 9,999$ ) to 1.9 in $2009-10$ (with the highest and the lowest vehicle crime risks faced by households at less than $£ 5,000$ and $£ 10,000-£ 19,999$, respectively). 
- Therefore, between 1995 and 2009-10 for both personal crime and vehicle theft the highest risks moved from the most affluent to the poorest residents of England and Wales. This reflects the greater falls in these crimes for the higher rather than the lower income groups resulting in divergence of risks and the better off also faring better in crime falls over time. Having said that, the second highest risks were faced by the poorest and the most affluent in 1995 and 2009-10, respectively.

- The highest burglary risks were faced by the lowest income group (less than $£ 5,000)$ in both 1995 and 2009-10. This population segment also enjoyed the smallest drop in burglary risk, thus exacerbating their already disadvantaged position in terms of burglary risk.

\section{Discussion}

This chapter has shown that between 1995 and 2009-10 there were substantial falls in crime for all the subgroups of household income, composition and tenure included in the analysis, that car theft has dropped more than burglary and that burglary has dropped more than personal crime. In terms of levels of victimization all groups appeared better off in 2009-10 than their (in the case of income, nominal) counterparts in 1995. For almost all categories the highest crime groups in 2009-10 had lower rates than the lowest crime groups in 1995. This is remarkable and reflects the great extent of the crime drop.

There are some differences between subgroups but no consistent pattern of convergence or divergence across crime types emerged from the analysis. There seemed to be corners 
of greater and lesser improvement in crime risk, which would warrant further interrogation. There are also some groups, notably single parents, poorest members of the community and private renters who continue to be at especially high risk compared to other groups and hence may warrant special crime prevention support. Each of these categories is heterogeneous and further work is needed to tease out more finely defined subgroups within the categories which are at greatest risk and why. Knowledge of this could inform the development of plausible, well-targeted preventive strategies.

The vulnerability differentials identified here may reflect levels of security, as well as the proximity, attractiveness and target availability to potential offenders (Cohen and Felson, 1979). With regard to theft of and from cars, although the better off plausibly provide prospective offenders with more attractive targets, rates of theft may be lower due to the greater security of the vehicles themselves and the places they are parked as well the relative inaccessibility of the neighborhoods where the most affluent citizens tend to live. The poorest may have less attractive cars and goods to steal from the vehicles, but their parking locations and inadequate car security may make them suitable targets for vehicle theft. With regard to burglary, the better off, especially owner occupiers, will tend to be less accessible (or less known about as targets) to likely offenders and may also have high levels of security that reduce risk, even though their houses will normally contain attractive goods to the prospective burglar. The risk of personal theft may be relatively high for the better off, both because they own more attractive goods and because they are out and about more often as prospective targets. By contrast, the very poorest may both be out less and have fewer attractive goods. This discussion is rather speculative, but 
highly plausible in the light of lifestyle/routine activities theory. It suggests a promising set of hypotheses for testing in future empirical research!

Ignoring for a moment the issue of proximity to potential offenders, this analysis suggests that different households may face varying crime risks due to differences in security levels. This notion may most obviously be applied when considering differential availability of anti-burglary and anti-car theft devices across tenure or income population subgroups. But it may also be relevant in regard to varying levels of guardianship afforded by households with different types of composition.

The link between security and reduced risk of burglary is not straightforward, although past BCS-based research showed that households with more security have lower burglary rates in England and Wales (Mayhew, Aye-Maung and Mirrlees-Black, 1993). The level of security cover is important: households with less-than-basic security experience six times more burglary than households with basic security (window locks plus double locks or deadbolts) and ten times more than those with enhanced security (Flatley et al., 2010: 2). But enhanced security does not confer any additional burglary with entry protection than basic security (Tseloni, 2011). The level of protection against burglary is therefore not fully proportionate to the investment in more and better security devices (Tilley, Tseloni and Farrell, 2011).

This conclusion is confirmed by the finding that the poorest households remained at the highest risk of burglary with entry. Their relative risk compared to more affluent households rose during the crime drops, despite the fact that households with less than $£ 10,000$ annual income enjoyed the highest increases in basic and enhanced security 
between 1995 and 2005-06 in England and Wales (Tilley et al., 2011). In reality, poor and rich households also differ in other respects relevant to their crime risks. These differences include tenure and accommodation type and the tendency of rich and poor to inhabit different neighborhoods which are associated with different patterns of proximity to potential burglars, levels of informal guardianship and social capital (Sampson and Wooldredge, 1987). The income differentials in burglary risk may therefore confound additional individual and area effects rather than being the simple consequence of more and better security. Security effects on burglary, in other words, are partly mediated or conditioned by household and area characteristics. This is brought out in a recent study which showed that enhanced home security in England and Wales is associated with area rather than household burglary (with entry) risks and that this relationship is mediated by household characteristics. Although in general households with a low level of security face increased burglary risks, some exhibit both high risk and high security levels (i.e., urban and inner city residents), while residents in some parts of the country enjoy low risks despite low security (Tseloni, 2011).

Our results regarding home security and differential drops in burglary risks in England and Wales can be compared with findings from an analysis of ICVS data from twelve Western countries (Van Dijk, 2008). This analysis has shown, first, that on average in these twelve countries since 1988 to 2004 high and middle level income groups have improved their home security more than low income groups. The relatively strong increase in home security in England and Wales among the lowest income group seems the result of interventions by the government. The analysis of ICVS data also shows that in the twelve countries on average burglary rates between 1988 and 2004 decreased by 
$30 \%$ among the upper income quartile and by $10 \%$ among the lowest quartile (Van Dijk, 2008). A comparison with our own findings concerning England and Wales suggests that government intervention has probably limited the rise in crime inequalities.

Previous studies have concluded that improvements to vehicle security contributed substantially to the overall falls in car theft. They also suggested that the falls in vehicle theft may in turn have contributed to falls in other crime types, both because vehicle theft is a 'debut crime' that presages other types of criminal activity and because the availability of stolen cars is a useful resource enabling other crime, although the evidence for this so far is scant (Farrell et al., 2011a). The current study's finding that the poorest households, which cannot afford new and more secure cars, had the highest vehicle theft risk in 2009-10, unlike 1995, is also consistent with a role for built-in car security devices in producing the falls in vehicle crime.

This chapter has been an early effort to examine volume crime inequality trends across a number of theoretically relevant socio-demographic characteristics, following Tilley et al. (2011), which, however, confined its attention to income-related differentials in burglary falls. More research is needed better to understand the relative extent of crime falls across different population subgroups and the relationship between falls of different crime types overall and across distinct population clusters.

By making use of appropriate regression analyses of each crime type of interest over individual and household socio-demographic characteristics and routine activities at each end of the crime drop period to date (i.e., drawing on the 1996 and the 2009-10 BCS data), future research will be able to identify how the respective crime victimization odds 
(and risks) altered for specific individual and household types (Tseloni et al., 2002). This research agenda has the advantage of estimating the contribution of each factor unconfounded with other characteristics, as in the case of the bivariate analyses presented here (Tseloni and Zarafonitou, 2008). For instance a large number of lone parents live in social housing, such that the individual contributions of household type and tenure to their victimization relative risks and drops evidenced in this work will be confounded. Furthermore, previous research has found that repeat victimization of some crime types has fallen significantly in England and Wales as well as internationally (Thorpe, 2007; Tseloni et al., 2010). The falls in relative incidence (rather than prevalence) rates of various population subgroups, which has not been addressed to date, will be equally, if not more, informative about the crime falls and their policy implications.

The final chapter of this book discusses a full research agenda for improving our understanding of the crime falls. This is important for criminology as an academic discipline. It is also relevant to policy. It may provide clues on how best to cut crime further or to contain any emerging increases in crime, such as those which appeared at the time of writing, to be emerging for domestic burglary and personal theft in England and Wales (Chaplin, Flatley and Smith, 2011). 


\section{References}

Chaplin, R. Flatley, J. and Smith, K. (2011) Crime in England and Wales 2010/11: Findings from the British Crime Survey and Police Recorded Crime, Home Office Statistical Bulletin, HOSB 10/11. London: Home Office.

Cohen, L.E. and Felson, M. (1979) Social Change and Crime Rates Trends: A Routine Activity Approach. American Sociological Review, 44, 588-608.

G. Farrell, N. Tilley, A. Tseloni, and Mailley, J. (2010) Explaining and sustaining the crime drop: Clarifying the role of opportunity-related theories Crime Prevention and Community Safety: An International Journal, 12(1), 24-41.

Farrell, G., Tseloni, A., Tilley, N. and Mailley, J. (2011a) The Crime Drop and the Security Hypothesis. Journal of Research in Crime and Delinquency, 48(2), 147-175.

Farrell, G., Tseloni, A. and Tilley, N. (2011b) The effectiveness of vehicle security devices and their role in the crime drop. Criminology and Criminal Justice, An International Journal, 13, 21-35.

Flatley, J., Kershaw, C., Smith, K., Chaplin, R. and Moon, D. (2010) Crime in England and Wales 2009/10: Findings from the British Crime Survey and Police Recorded Crime, London: Home Office.

Gottfredson, M.R. (1981) On the Etiology of Criminal Victimisation. Journal of Criminal Law and Criminology, 72, 714-726.J. Hales and N. Stratford (1997) 1996 British Crime Survey (England and Wales): technical report, London: SCPR.

Hindelang, M.J., Gottfredson, M.R. and Garofalo, J. (1978) Victims of Personal Crime: 
An Empirical Foundation for a Theory of Personal Victimisation. Cambridge Mass: Ballinger Publishing Company.

Home Office. Research, Development and Statistics Directorate and BMRB. Social Research, British Crime Survey; 1996 - 2010. Colchester, Essex: UK Data Archive [distributor].

Karmen, A. (2001) Crime Victims: An Introduction to Victimology. Fourth Edition. Stamford, CT: Wadsworth Thompson Learning.

Lauritsen, J. (2001) Race, gender, place and risk: Patterns of violent victimisation in the National Crime Victimisation Survey (NCVS). Proceedings of the American Statistical Association.

Mayhew, P. Aye Maung, N., Mirlees-Black, C. (1993) The 1992 British Crime Survey, Home Office Research Study No. 132. London: HMSO.

Miethe T. D., Stafford, M. C. and Long, S. J. (1987) Social differentiation in criminal victimisation: A test of routine activities/lifestyle theories. American Sociological Review, 52, 184-194.

Sampson, R.J. and Wooldredge, J.D. (1987) Linking the Micro- and Macro-Level Dimensions of Lifestyle-Routine Activity and Opportunity Models of Predatory Victimization. Journal of Quantitative Criminology, 3, 371-393.

Tilley, N. Tseloni, A. and Farrell, G. (2011) Income disparities of burglary risk and security availability during the crime drop. British Journal of Criminology, 51(2), 296313. 
TNS-BMRB (2010) British Crime Survey 2009-10 Technical Report. London: TNSBMRB.

Tseloni, A. (2006) Multilevel modelling of the number of property crimes: Household and area effects. Journal of the Royal Statistical Society Series A-Statistics in Society, 169, Part 2, 205-233.

Tseloni, A. (2010) Individual and contextual risk factors of personal victimisation in England and Wales. Interdisciplinary workshop on 'Urban social dynamics: inequalities, segregation and criminality', EHESS. Paris. 16 November. Available online: http://cams.ehess.fr/docannexe.php?id=1011.

Tseloni, A. (2011) Household burglary victimisation and protection measures: Who can afford security against burglary and in what context does it matter? British Crime Survey Users Meeting, Royal Statistical Society, London. 13 December. Available online: http://www.ccsr.ac.uk/esds/events/2011-12-13/index.html.

Tseloni, A. and Pease, K. (2005), Population Inequality: The Case of Repeat Victimisation. International Review of Victimology, 12, 75-90. Tseloni, A. Mailley, J. Farrell, G. and Tilley, N. (2010) The cross-national crime and repeat victimization trend for main crime categories: Multilevel modeling of the International Crime Victims Survey. European Journal of Criminology 7(5): 375-394

Tseloni, A. and Zarafonitou, C. (2008) Fear of crime and victimisation: A multivariate multilevel analysis of competing measurements. European Journal of Criminology, 5(4), 387-409. 
Tseloni, A. Osborn, D.R. Trickett, A. and Pease, K. (2002) 'Modelling property crime using the British Crime Survey: What have we learned?' British Journal of Criminology, $42,89-108$.

Van Dijk, J.J.M. (2008). The world of crime: Breaking the silence on problems of security, justice and development across the world. Thousand Oaks: Sage. 
Figure 1: British trends in vehicle theft, domestic burglary and personal crime.



Note: The years shown on the horizontal axis are those when there was a British Crime Survey Sweep 
Table 1: Risk variations for vehicle theft, burglary with entry and personal crime across household tenure, income and composition in the 1996 BCS. $^{\text {a }}$

\begin{tabular}{|c|c|c|c|}
\hline & Vehicle theft $^{\mathrm{b}}(\%)$ & Burglary with entry (\%) & Personal crime $(\%)$ \\
\hline \multicolumn{4}{|l|}{ Tenure } \\
\hline Own & 15.8 & 3.5 & 9.9 \\
\hline Social rent & 19.7 & 5.9 & 12.9 \\
\hline Private rent & 21.3 & 6.2 & 19.7 \\
\hline Other & 18.4 & 6.2 & 13.6 \\
\hline$\chi^{2}$ (p-value) & $26.495(<0.001)$ & $54.024(<0.001)$ & $109.916(<0.001)$ \\
\hline \multicolumn{4}{|l|}{ Household income } \\
\hline Under $£ 4,999$ & 17.6 & 5.6 & 11.6 \\
\hline$£ 5,000-£ 9,999$ & 14.0 & 3.9 & 8.9 \\
\hline$£ 10,000-£ 19,999$ & 15.3 & 3.6 & 10.8 \\
\hline$£ 20,000-£ 29,999$ & 18.0 & 3.5 & 12.1 \\
\hline$£ 30,000$ and over & 20.0 & 4.1 & 13.2 \\
\hline$\chi^{2}$ (p-value) & $36.919(<0.001)$ & $29.963(<0.001)$ & $32.315(<0.001)$ \\
\hline \multicolumn{4}{|l|}{ Household composition } \\
\hline 1 adult, children & 23.0 & 10.4 & 21.5 \\
\hline 2-3 adults, children & 18.5 & 3.9 & 12.3 \\
\hline 1-2 adults, no children & 13.9 & 3.9 & 9.4 \\
\hline $3+$ adults, no children & 21.5 & 3.5 & 14.5 \\
\hline$\chi^{2}(\mathrm{p}$-value $)$ & $80.595(<0.001)$ & $91.464(<0.001)$ & $155.031(<0.001)$ \\
\hline Overall rate & 16.7 & 4.3 & 11.3 \\
\hline
\end{tabular}


Table 2: Risk variations for vehicle theft, burglary with entry and personal crime across household tenure, income and composition in the 2009-10 BCS. ${ }^{\text {a }}$

\begin{tabular}{|c|c|c|c|}
\hline & Vehicle theft ${ }^{\mathrm{b}}(\%)$ & Burglary with entry (\%) & Personal crime (\%) \\
\hline \multicolumn{4}{|l|}{ Tenure } \\
\hline Own & 4.0 & 1.0 & 4.6 \\
\hline Social rent & 5.0 & 2.2 & 6.6 \\
\hline Private rent & 5.2 & 2.3 & 8.3 \\
\hline Other & 3.8 & 2.0 & 8.2 \\
\hline$\chi^{2}$ (p-value) & $18.494(<0.001)$ & $99.280(<0.001)$ & $140.482(<0.001)$ \\
\hline \multicolumn{4}{|l|}{ Household income } \\
\hline Under $£ 4,999$ & 6.2 & 2.7 & 9.6 \\
\hline$£ 5,000-£ 9,999$ & 4.4 & 1.8 & 5.6 \\
\hline$£ 10,000-£ 19,999$ & 3.3 & 1.3 & 4.7 \\
\hline$£ 20,000-£ 29,999$ & 4.0 & 1.1 & 5.5 \\
\hline$£ 30,000-£ 49,999$ & 4.2 & 1.1 & 5.5 \\
\hline$£ 50,000$ and over & 5.9 & 1.4 & 6.0 \\
\hline$\chi^{2}$ (p-value) & $82.142(<0.001)$ & $48.035(<0.001)$ & $113.773(<0.001)$ \\
\hline Household composition & & & \\
\hline 1 adult, children & 6.5 & 3.7 & 8.4 \\
\hline 2-3 adults, children & 5.4 & 1.5 & 5.6 \\
\hline 1-2 adults, no children & 3.0 & 1.1 & 4.6 \\
\hline $3+$ adults, no children & 6.3 & 1.5 & 7.3 \\
\hline$\chi^{2}$ (p-value) & $169.017(<0.001)$ & $117.504(<0.001)$ & $109.143(<0.001)$ \\
\hline Overall rate & 4.2 & 1.3 & 5.3 \\
\hline
\end{tabular}

${ }^{\mathrm{a}}$ Raw data, BCS adult and household weights have not been used.

${ }^{\mathrm{b}}$ The basis refers to car and van owning households. 
Table 3: Percentage falls in vehicle theft, burglary and personal crime from 1995 to 2009-

10.

\begin{tabular}{lrrr}
\hline & $\begin{array}{c}\text { Vehicle theft, } \\
\text { car owners }\end{array}$ & $\begin{array}{c}\text { Burglary with } \\
\text { entry }\end{array}$ & Personal crime \\
\hline Tenure & 75.0 & 71.4 & 53.5 \\
Own & 74.4 & 63.1 & 48.8 \\
Social rent & 75.4 & 63.1 & 57.8 \\
Private rent & 79.3 & 67.1 & 40.0 \\
Other & & & \\
\hline Household income & 64.6 & 51.8 & 17.6 \\
Under £4,999 & 68.7 & 53.8 & 37.6 \\
$£ 5,000$ - £9,999 & 78.5 & 63.9 & 56.8 \\
$£ 10,000$ - £19,999 & 77.7 & 68.6 & 54.3 \\
$£ 20,000$ - £29,999 & 79.2 & 73.2 & 58.0 \\
$£ 30,000$ - £49,999* & 70.5 & 65.9 & 54.5 \\
$£ 50,000$ and over* & & & 60.9 \\
\hline Household composition & 71.7 & 64.3 & 54.4 \\
1 adult, children & 70.7 & 62.0 & 50.7 \\
2-3 adults, children & 78.1 & 73.0 & 49.3 \\
1-2 adults, no children & 70.6 & 57.1 & 52.9 \\
$3+$ adults, no children & & & 69.1 \\
\hline
\end{tabular}

*Both these compare the 2009-10 rates with that for $£ 30,000$ and over in 1996 which was the highest household income category.

\footnotetext{
' The BCS employs the adult and household weights that adjust the sample size to represent the respective populations in England and Wales. This analysis however does not use the BCS weights because as it is concerned with trends and assuming that the mean household size has remained stable during this period their employment (or not) is not expected to affect the results.
} 